\title{
Formulation and implementation of educational policies in Nigeria
}

\author{
Jonathan Adedayo Odukoya ${ }^{1,2 \star}$, Ebenezer Bowale ${ }^{3}$ and Sola Okunlola ${ }^{1}$ \\ ${ }^{1}$ Department of Psychology, Covenant University, Nigeria. \\ ${ }^{2}$ Educational Research Network for West and Central Africa, Nigeria. \\ ${ }^{3}$ Department of Economics, Covenant University, Nigeria.
}

Accepted 11 December, 2017

\begin{abstract}
The paper reviewed the formulation and implementation of the Nigerian national policy of education that was enacted in 1977. Though the document featured lot of laudable policies, feedback from key stakeholders in education revealed that the implementation of the policy was deficient and need urgent attention for the country to experience the much need development.
\end{abstract}

Keywords: Learning, educational policies, formulation, implementation, Nigeria, national policy of education, development.

*Corresponding author. E-mail: dayoodukoya@gmail.com.

\section{INTRODUCTION}

The importance of education to the general well-being of mankind cannot be overemphasized. Education is a fundamental human right. The relationship between education and development has been established, such that education is now internationally accepted as a key development index (UNDP, 2016). It is in recognition of this importance that the international community and governments all over the world have made commitments for its citizens to have access to education.

\section{Background}

Over the years, Nigeria has expressed a commitment to education, with the belief that overcoming illiteracy and ignorance will form a basis for accelerated national development. However, regardless of the incontrovertible evidence that education is crucial to the development of the community and the nation, there remain inequalities in access to education in Nigeria. Despite its potential for leveling opportunities, education is pathetically used to perpetrate inequalities. Millions of poor people are still being excluded from the processes and outcomes of education.

\section{THE STATE OF EDUCATION IN NIGERIA}

The severe decline of the oil market in the early eighties, combined with the Structural Adjustment Programme (SAP), led to drastic reductions in spending on education in Nigeria. The result was unpaid teacher salaries, degradation of education facilities at all levels and strikes in universities/public schools, culminating in declining literacy rates.

The poor state of education in Nigeria is aptly captured in the National Empowerment Development Strategy (IMF, 2005) as follows:

'...the delivery of education in Nigeria has suffered from years of neglect, compounded by inadequate attention to policy frameworks within the sector. Findings from an ongoing educational sector analysis confirm the poor state of education in Nigeria. The national literacy rate is currently 57 percent. Some 49 percent of the teaching force is unqualified. There are acute shortages of infrastructure and facilities at all levels. Access to basic education is inhibited by gender issues and socio-cultural 
beliefs and practices, among other factors. Wide disparities persist in educational standards and learning achievements. The system emphasizes theoretical knowledge at the expense of technical, vocational, and entrepreneurial education. School curricula need urgent review to make them relevant and practice oriented'.

\section{The challenges of policy implementation}

For about forty years now, Nigeria has been unable to successfully implement the National Policy on Education [NPE]. The policy which came into existence in 1977, after over four years of deliberations at various levels, appeared to have solutions to virtually all core educational problems (FME, 1977). However, there are apparent serious problems in the area of implementation. Some of them are highlighted below:

\section{Nigeria's philosophy of education}

In Section 1 Sub-Section 5, the NPE states that the Nigeria's philosophy of education is based

on the development of the individual into a sound and effective citizen. The policy further stressed the full integration of the individual into the community, and the provision of equal access to educational opportunities for all citizens of the country at the primary, secondary and tertiary levels both inside and outside the formal school system.

With an estimated human population of $140,003,542$, illiteracy is still as high as $60 \%$. No Nigerian Newspaper has a daily print run of 500,000 copies. There are thousands of educated but unemployed Nigerian youths who cannot pay taxes. These people cannot be described in the words of NPE as "effective citizens." There are also few educated elites who have looted the treasury so massively that they could hardly be described as "effective citizens."

\section{Policy on language}

In Section 1 Sub-section 10, the policy talks about the importance of language. It says:

"government appreciates the importance of language as a means of promoting social interaction and national cohesion and preserving cultures. Thus every child shall learn the language of the immediate environment... Furthermore, in the interest of national unity it is expedient that every child shall be required to learn one of the three Nigerian languages, Hausa, Igbo and Yoruba. For smooth interaction with our neighbours it is desirable for every
Nigerian to speak French. Accordingly, French shall be the second official language in Nigeria and it shall be compulsory in schools."

Forty years after the enactment of the policy, French is taught in few public/private primary and secondary schools. Many Nigerian schools have no French teacher.

\section{Policy on pre-primary education}

The National Policy on Education has also been poorly implemented in the area of pre-primary education. In Section 2 the policy says

"The responsibilities of government for preprimary education shall be to promote the training of qualified pre-primary school teachers in adequate number and supervise and control the quality of such institution"

This is another aspect of the policy that has not been implemented at all, especially at the federal level. The Lagos State College of Primary Education [LASCOPED] is perhaps the only institution in Nigeria that specializes in the training of pre-primary school teachers.

\section{Policy on teachers' registration council}

The National Policy on Education in Section 9 subsection 79 suggested that there should be Teachers Registration Council. Between 1977 and 1993 nothing was done to establish the Teachers Registration Council. In 1993 Decree 31 established the council. For another six years nothing was done to implement the provisions of the decree until 1999 when the first Registrar and Chief Executive of the Council was appointed. To date, only few teachers have been registered while many still do not know of its existence.

\section{Frequent changes in policies}

Politics and frequent changes in government tend to negatively affect the implementation of the National Policy on Education. Professor Ajayi, one time Provost of Federal College of Education (FCE) Osiele, Ogun State in Nigeria made this observation:

"Within the eight years (1991-1999) that I served as Provost, the nation passed through five different regimes (Babangida till 1993, Shonekan for less than four months in 1993, Abacha 1993-1998, Abubakar 1998-1999, Obasanjo 1999-2007). Within this period I had to operate under eight Ministers of Education. The same thing happened at the state level. Each of 
the Presidents, Ministers, Governors and Commissioners had their own different conceptions and policies on education that they tried to implement during their tenure. With such instability in the system of governance, coupled with constant changes in "Ministers of" "Ministers for" and "commissioners for," one should not be surprised at the level of the crises the nation's education system has witnessed over the years and the inconsistency and often contradictory nature of the educational policies and practices. It's one step forward and two steps backward".

\section{A NEW SYSTEM OF EDUCATION}

Presently, the Nigerian government has come up with another system of education tagged 9-3-4 system. The first one known as 6-3-3-4 was never fully implemented, and now this. Mrs. Bola Mosuro, the Proprietress of Access Universal College, Lagos lamented:

"Our problem in this country [Nigeria] is that we often pick and drop policies as we want. In the United States the two tier secondary school system is still in operation delivering wonderful results. There is nothing wrong with the 6-3-3-4 system. We simply have not implemented it well and now we have picked another one."

\section{Policy on science and technology}

Less than $50 \%$ of graduates of tertiary institutions in Nigeria are products of science and technology institutions. Graduates of humanities and social sciences are far more than that of science and technology. This is contrary to the National Policy on Education which recommended $70 \%$ admission into science and technology programmes.

\section{Policy on technical colleges}

While the NPE puts the ratio between secondary and technical vocational education/schools at 3:1, Nigeria has 5,100 secondary schools with enrolment of $4,448,991$ as against technical colleges of only 169 with enrolment of 43,354 representing ratios of $37: 1$ and 102:1 respectively.

According to the policy, technical colleges are expected to feed polytechnics just as secondary schools are to feed universities. The prevailing situation however is that the total products of Nigerian technical colleges represent only $17 \%$ of available spaces in polytechnics. So, right from the onset, the mission of technical colleges concerning feeding polytechnic is not being met. Consequently, the country tends to be producing more theoreticians than technology experts.

\section{Differential remunerations for graduates of polytechnics and universities}

As long as entrants of Technical Colleges cum Polytechnics are classified as the poorer students emanating from the Junior Secondary Schools [JSS] while it is the 'bright' JSS students that are admitted into Senior Secondary Schools [SSS] and Universities, there is bound to be differential treatment of their respective graduates.

For Africa to keep pace with technological development around the world, something quick and pragmatic has to be done to redress the serious problem that tends to be eroding the little gains of the 6-3-3-4 education system. Perhaps all Polytechnics should be upgraded to Universities of Technology.

\section{Policy on private universities}

In 1960/61 there were only two universities in Nigeria while the total student population stood at only 1,395. This figure rose to 32,282 in 13 universities by 1975 , 116,822 in 27 universities by 1983 and 180,871 in 31 universities by 1990 . Even the recent 22 private universities, 25 federal universities and 27 state universities are still far from accommodating the number of students who qualified for admission.

In fact, out of over one million Nigerian students that applied for university admission less than $25 \%$ could be absorbed. This is due to the poor implementation of the policy which had long recommended greater expenditure on education to create more space for the youths.

\section{Policy on ICT}

The Federal Executive Council approved a national IT policy in March 2001 and the implementation started in April with the establishment of the National Information Technology Development Agency (NITDA), charged with the implementation responsibility. The policy recognized the private sector as the driving engine of the IT sector.

The policy is however overdue for review due to changes and advances in ICT globally and in Nigeria. Consequently, government inaugurated the Nigerian National ICT for Development (ICT4D) Strategic Action Plan committee to develop a new ICT policy vis-à-vis action plan/roadmap for the nation.

\section{Need for good understanding of the process of policy formulation}

There is dire need for a good understanding of the 
process of policy formulation. This understanding is apt to positively influence our research methodology and reporting system. It is also likely to enhance the acceptability of our research findings for policy formulation.

\section{Lobbying and advocacy}

There is also a dire need for a thorough understanding of the principles and operation of lobbying and advocacy. It is becoming common knowledge that the correct application of these indispensable principles is vital for the successful translation of research findings into national educational policy formation and implementation.

Bureaucratic bottlenecks, which are common in many developing African countries, further elongates the period of policy formulation. This, therefore, often necessitates the need to patiently wait on the policy administrators for days on end. This naturally translates to more expenses on hotel accommodation, feeding, transportation and communication expenses. These expenses are hardly budgeted for in our research studies, hence the paucity of research findings that have been successfully translated into national policies in Nigeria to date.

\section{Policy formulation versus policy implementation}

Furthermore, it is one thing to succeed in getting research findings translated into national policies; it is another ballgame altogether getting them implemented. This may often necessitate further follow-up and intensive lobbying.

Part of the problem here has to do with incessant changes in government and paucity of technocrats within the government. Lack of understanding of the power of well-formulated policy and diligent implementation in effecting educational and national development apparently account for this.

\section{WAY FORWARD}

1. Establish a standard for conducting research [research method] and for reporting - from problem identification, title formulation, proposal writing, sampling, instrument development and validation, fieldwork, data analysis, result presentation, abstract writing and referencing.

2. Institute an annual specialized seminar/training session on the significance and process of policy formulation and implementation for researchers and for key government functionaries.

3. Institute an annual specialized training on effective advocacy and lobbying strategies (same audience).
4. Evolve research themes that have strong bearing on the formulation and implementation of national educational policies.

5. Budget adequately for these seminars/training programmes and for the necessary logistics to follow-up and follow-through on getting our research findings adopted for policy formulation and implementation.

\section{FINAL WORDS}

The cost of advocating and lobbying to get our research findings adopted for policy formulation and implementation is a far cry from the colossal amount that have been spent on unutilized research efforts in the part decades. This colossal waste would be significantly reduced, and with time, totally eliminated by venturing to spend a little more on carrying advocacy/lobbing to a logical conclusion. This is the thrust of this paper.

\section{REFERENCES}

Federal Ministry of Education (1977). National Policy on Education. Lagos: FMoE.

International Monetary Fund (IMF) (2005). 'National Economic Empowerment and Development Strategy [NEEDS]'. IMF Country Report No. 05/433 Abuja: Nigerian National Planning Commission.

United Nations Development Program (UNDP) (2016). Human Development Report - Human Development for Everyone. NewYork: UNDP. \begin{tabular}{l}
\hline Citation: Odukoya, J. A., Bowale, E., and Okunlola, S. (2018). \\
Formulation and implementation of educational policies in Nigeria. \\
African Educational Research Journal, 6(1): 1-4.
\end{tabular} 